\title{
LENGTH-WEIGHT RELATION FOR ELEVEN DEMERSAL FISH SPECIES IN THE ARTISANAL SHRIMP FISHERY AREAS FROM THE BAHIA MAGDALENA- ALMEJAS LAGOON SYSTEM, MEXICO
}

\author{
Carlos H. RÁBAGO-QUIROZ ${ }^{1 *}$, Juan A. GARCÍA-BORBÓN ${ }^{1}$, \\ Deivis S. PALACIOS-SALGADO², and Francisco J. BARRÓN-BARRAZA ${ }^{1}$ \\ ${ }^{1}$ Instituto Nacional de Pesca y Acuacultura, Centro Regional de Investigación Acuícola y Pesquera, La Paz, \\ Baja California Sur, México \\ ${ }^{2}$ Colección Ictiológica, Escuela Nacional de Ingeniería Pesquera, Universidad Autónoma de Nayarit, Bahía de \\ Matanchén, San Blas, México
}

\begin{abstract}
Rábago-Quiroz C.H., García-Borbón J.A., Palacios-Salgado D.S., Barrón-Barraza F.J. 2017. Length-weight relation for eleven demersal fish species in the artisanal shrimp fishery areas from the Bahia MagdalenaAlmejas lagoon system, Mexico. Acta Ichthyol. Piscat. 47 (3): 303-305.
\end{abstract}

\begin{abstract}
The length-weight relations $(L-W)$ for 11 demersal fish species from a lagoon system in south-western coast of the Baja California Peninsula, Mexico were estimated. The following species were studied: Occidentarius platypogon (Günther, 1864); Balistes polylepis Steindachner, 1876; Diplectrum pacificum Meek et Hildebrand, 1925; Paralabrax maculatofasciatus (Steindachner, 1868); Eucinostomus gracilis (Gill, 1862); Eucinostomus dowii (Gill, 1863); Etropus crossotus Jordan et Gilbert, 1882; Etropus peruvianus Hildebrand, 1946; Haemulopsis axillaris (Steindachner, 1869); Orthopristis chalceus (Günther, 1864); and Orthopristis reddingi Jordan et Richardson, 1895. These species were caught in the artisanal shrimp fishery areas from the Bahia MagdalenaAlmejas lagoon system; thus the specimens were obtained with the shrimp trawl net. A total of 3824 specimens were used to estimate parameters of the relations. The slope $(b)$ fell within 2.7 to 3.4 and the growth pattern was isometric in most cases (10 species), whereas for one species the growth was allometric. The $L-W$ relation parameters for Occidentarius platypogon and Eucinostomus peruvianus, are not available in FishBase.
\end{abstract}

Keywords: shrimp trawl, morphometric study, Occidentarius platypogon, potential model, Mexican Pacific

The length-weight $(L-W)$ relations were estimated for 11 demersal fish species caught in a lagoon system from the Mexican North Pacific_-Bahia Magdalena-Almejas, Baja California Sur (B.C.S.). This is one of the most productive coastal systems in Mexico (García-Martínez and ChávezOrtiz 2007), of which, besides the sardine industrial fishery, artisanal fisheries of several molluscs, crustaceans, and fish species are developed. During 1997-1998 to 2015-2016, the average contribution of the artisanal shrimp fishery is around $1000 \mathrm{t}$ per season (Anonymous 2015), which occurs from September to March, with an actual effort of 450 small boats called pangas (García-Borbón unpublished ${ }^{* *}$ ). In this fishery there is a closed fishing season which occurs from March to September (Anonymous 2017).

There is scarce of information regarding the biology of these demersal fish species, which have an intense fishing pressure during the commercial season (García-Borbón unpublished*). The results obtained in the presently reported study can be used to derive weight estimates for unweighed but measured fish, and assist in estimating the biomass of important commercial fish species, like Balistes polylepis Steindachner, 1876 and Paralabrax maculatofasciatus (Steindachner, 1868), captured in this important lagoon system. This report is a first approach to study of the $L-W$ relation of demersal fish species in this area.

Samples were collected during 11 surveys from March to August 2014 (only the closed shrimp fishing season) and from April through December 2015 (which coincided with closed and open shrimp fishing season) in the Bahia Magdalena-Almejas lagoon system. The lagoon system is located in the south-western coast of

\footnotetext{
* Correspondence: Dr Carlos H. Rábago-Quiroz, Instituto Nacional de Pesca y Acuacultura, Centro Regional de Investigación Acuícola y Pesquera, La Paz, B.C.S. Carretera a Pichilingue Km. 1 S/N, Col. El Esterito, La Paz, Baja California Sur, 23020, México, phone: +52 612 122 1367, e-mail: (CHRQ) carlos.rabago@inapesca.gob.mx, (JAGB) antonio.borbon@inapesca.gob.mx, (DSPS) palaciossalgado@gmail.com, (FJBB) fbarron.uabcs@gmail.com.

*"García-Borbón J.A. 2009. Construcción de un modelo estructurado por edades para la determinación del inicio de temporada de captura de camarón café (Farfantepenaeus californiensis, Holmes) en Bahía Magdalena-Almejas, Baja California Sur, México. Master of Science thesis. Instituto Politécnico Nacional (CICIMAR), La Paz, B.C.S., México.
} 
the Baja California Peninsula, Mexico $\left(24^{\circ} 50^{\prime}-24^{\circ} 20^{\prime} \mathrm{N}\right.$ and $\left.112^{\circ} 11^{\prime}-111^{\circ} 29^{\prime} \mathrm{W}\right)$. Monthly biological surveys were conducted during the closed shrimp fishing season in the sampling stations spread across the shrimp trawling grounds and were the same as those sampled annually by Mexican fisheries authorities (Instituto Nacional de Pesca) to assess the shrimp population and the associated fauna. From September through December (open shrimp fishing season), samples were obtained monthly from sites where the artisanal fleet operated. The fishing gear used in all surveys was the shrimp trawl net fitted with 16-17 m footrope and $35 \mathrm{~mm}$ liner at the codend.

The fishes caught were stored on ice and transported to the laboratory where they were frozen. Before freezing the fishes were identified to the species level using keys and descriptions of Fisher et al. (1995) and Robertson and Allen (2015). All captured specimens were measured (total length, TL) with an ichthyometer $( \pm 0.1 \mathrm{~mm})$ and weighed (total weight, TW) with an electronic balance $( \pm 0.1 \mathrm{~g})$. Reference specimens from each fish species were preserved in ethanol (after fixing in formalin) in the Centro Regional de Investigación Acuícola y Pesquera (CRIAP), located in La Paz, B.C.S., Mexico.

The $L-W$ relation was estimated for each species by the potential model

$$
W=a \mathrm{TL}^{b}
$$

where $W$ is the total weight $(\mathrm{g})$, TL is the total length $(\mathrm{cm})$, $a$ is the intercept, and $b$ is the slope. Prior to regression analysis, log-log plots of the length-weight pairs were performed to identify outliers (Froese et al. 2011). Extreme outliers were excluded from the analysis. The $95 \%$ confidence limits for $b$ were calculated to determine whether the hypothetical value of isometry (3) fell between these limits. To determine the type of growth, the $b$ values for each species were compared with the isometric value using the $t$-Student test ( $\operatorname{Zar} 2014$ ). If $b=3$, growth is isometric, if $b \neq 3$ growth is allometric (Ricker 1975).

A total of 3824 specimens belonging to 11 species and six families were analysed: Ariidae and Balistidae (each with one species), Serranidae, Gerreidae, Paralichthyidae (each with two species), and Haemulidae (each with three species).

There were 11 most abundant and common demersal fish species in the artisanal shrimp fishery areas from the Bahia Magdalena-Almejas lagoon system: Occidentarius platypogon (Günther, 1864); Balistes polylepis Steindachner, 1876; Diplectrum pacificum Meek et Hildebrand, 1925; Paralabrax maculatofasciatus (Steindachner, 1868); Eucinostomus gracilis (Gill, 1862); Eucinostomus dowii (Gill, 1863); Etropus crossotus Jordan et Gilbert, 1882; Etropus peruvianus Hildebrand, 1946; Haemulopsis axillaris (Steindachner, 1869); Orthopristis chalceus (Günther, 1864); and Orthopristis reddingi Jordan et Richardson, 1895. These 11 species constituted more than $81 \%$ of total fish abundance. At least 100 specimens were analysed for each of these species.

The sample sizes $(n)$, length and weight ranges, regression parameters of the $L-W$ relations ( $a$ and $b$ ), 95\% confidence interval (CI) of $a$ and $b$, and the coefficient of determination $r^{2}$ by species are presented in Table 1 .

Length-weight relation for 11 demersal fish species in the artisanal shrimp fishery areas

Table 1 from the Bahia Magdalena-Almejas lagoon system, Mexico

\begin{tabular}{|c|c|c|c|c|c|c|}
\hline \multirow{2}{*}{ Species } & \multirow{2}{*}{$\mathrm{n}$} & \multirow{2}{*}{ Length $[\mathrm{cm}]$} & \multirow{2}{*}{ Weight $[\mathrm{g}]$} & \multicolumn{3}{|c|}{ Regression parameters } \\
\hline & & & & $a \pm \mathrm{CI} 95 \%$ & $b \pm \mathrm{CI} 95 \%$ & $r^{2}$ \\
\hline \multicolumn{7}{|l|}{ Family Ariidae } \\
\hline Occidentarius platypogon & 367 & $9.7-25.7$ & $6.4-144.0$ & $0.004 \pm 0.001$ & $3.200 \pm 0.041$ & 0.981 \\
\hline \multicolumn{7}{|l|}{ Family Serranidae } \\
\hline Diplectrum pacificum & 406 & $7.7-24.0$ & $4.6-172.0$ & $0.005 \pm 0.001$ & $3.246 \pm 0.059$ & 0.965 \\
\hline Paralabrax maculatofasciatus & 464 & $9.4-29.8$ & $11.0-328.0$ & $0.016 \pm 0.002$ & $2.928 \pm 0.035$ & 0.976 \\
\hline \multicolumn{7}{|l|}{ Family Gerreidae } \\
\hline Eucinostomus gracilis & 828 & $7.8-17.4$ & $6.2-60.0$ & $0.012 \pm 0.001$ & $3.027 \pm 0.044$ & 0.952 \\
\hline Eucinostomus dowii & 657 & $8.4-17.5$ & $8.2-78.0$ & $0.008 \pm 0.001$ & $3.170 \pm 0.063$ & 0.928 \\
\hline \multicolumn{7}{|l|}{ Family Haemulidae } \\
\hline Haemulopsis axillaris & 131 & $9.3-22.0$ & $11.0-127.0$ & $0.023 \pm 0.007$ & $2.789 \pm 0.108$ & 0.953 \\
\hline Orthopristis chalceus & 141 & $10.8-19.5$ & $17.0-95.0$ & $0.012 \pm 0.005$ & $2.983 \pm 0.153$ & 0.923 \\
\hline Orthopristis reddingi & 121 & $11.0-21.2$ & $15.0-118.0$ & $0.012 \pm 0.017$ & $3.014 \pm 0.145$ & 0.935 \\
\hline \multicolumn{7}{|l|}{ Family Paralichthyidae } \\
\hline Etropus crossotus & 363 & $5.7-18.1$ & $2.2-69.0$ & $0.009 \pm 0.001$ & $3.065 \pm 0.030$ & 0.984 \\
\hline Etropus peruvianus & 200 & $6.1-20.0$ & $2.0-89.0$ & $0.010 \pm 0.001$ & $3.025 \pm 0.029$ & 0.988 \\
\hline \multicolumn{7}{|l|}{ Family Balistidae } \\
\hline Balistes polylepis & 101 & $5.8-31.0$ & $5.1-441.0$ & $0.042 \pm 0.008$ & $2.701 \pm 0.066$ & 0.982 \\
\hline
\end{tabular}

$n=$ sample size; Length = total length range; Weight = total weight; $a=$ intercept, $b=$ slope, $r^{2}=$ coefficient of determination, $\mathrm{CI}=95 \%$ confidence interval. 
All relations were highly significant (for all $r^{2}>0.92$, $P<0.05)$ and $b$ ranged from 2.70 to 3.24 . In most cases (10 species) the growth type was isometric and only for Balistes polylepis was allometric.

We consider results presented in this report an adequate estimation of $L-W$ relation for the eleven species, because the parameter $b$ fell within the expected range of 2.6-3.4 (Froese et al. 2011), and the threshold of a minimum number of sampled fishes (100 specimens for each species) was also reached (Froese 2006, Froese et al. 2011).

The $L-W$ relation for Occidentarius platypogon and Etropus peruvianus, are not available in FishBase (Froese and Pauly 2017). For the other nine species, $L-W$ parameters are available in FishBase, though these are referring to others areas (South Mexican Pacific) or highly restricted sites (Gulf of California), and the confidence intervals of $b$ are not available.

Large ranges of lengths were used for all 11 fish species (the specimens used included both juveniles and adults). However, the estimates obtained should be used with caution outside of length ranges indicated in this report.

\section{ACKNOWLEDGEMENTS}

Financial support was received from INAPESCA (CRIAP-La Paz, B.C.S.) "Camarón de Baja California Sur, 2014" grant. The first author is grateful to Arturo Robles who helped with sampling and Diana Dorantes for English editing.

\section{REFERENCES}

Anonymous 2015. Anuario Estadístico de Acuacultura y Pesca 2015. Comisión Nacional de Acuacultura y Pesca (CONAPESCA), México.

Anonymous 2017. Análisis del comportamiento de la pesquería de camarón en el litoral Pacífico mexicano en la temporada 2016-2017, para la implementación del inicio de veda en el 2017. Dictamen Técnico. Instituto Nacional de Pesca (INAPESCA). Mazatlán, Sinaloa, México.

Fischer W., Krupp F., Schneider W., Sommer C., Carpenter K.E., Niem V.H. 1995. Guía FAO para la identificación de especies para los fines de pesca, Pacífico Centro-Oriental. Volumes II and III. Vertebrados- Partes 1 and 2. FAO, Roma.

Froese R. 2006. Cube law, condition factor and weightlength relationships: History, meta-analysis and recommendations. Journal of Applied Ichthyology 22 (4): 241-253. DOI: $10.1111 / \mathrm{j} .1439-0426.2006 .00805 . \mathrm{x}$

Froese R., Tsikliras A.C., Stergiou K.I. 2011. Editorial note on weight-length relations of fishes. Acta Ichthyologica et Piscatoria 41 (4): 261-263.

DOI: $10.3750 / \mathrm{AIP} 2011.41 .4 .01$

Froese R., Pauly D. (eds.) 2017. FishBase. [Version 06/2017] www.fishbase.org

García-Martínez S., Chavéz-Ortíz E. 2007. La pesquería de camarón en Puerto San Carlos, Bahía Magdalena: Una perspectiva socioeconómica. Pp. 277-288. In: Funes-Rodríguez R., Gómez-Gutiérrez J., PalomaresGarcía R. (eds.) Estudios Ecológicos en Bahía Magdalena. Instituto Politécnico Nacional, México.

Ricker W.E. 1975. Computation and interpretation of biological statistics of fish populations. Bulletin of the Fisheries Research Board of Canada No. 191.

Robertson D.R., Allen G.R. 2015. Peces costeros del Pacífico oriental tropical: Sistema de información en línea. Versión 2.0. Instituto Smithsoniano de Investigaciones Tropicales, Balboa, Republica de Panamá. http://biogeodb.stri.si.edu/sftep/es/pages

Zar J.H. 2014. Biostatistical analysis. 5th edn. Pearson Education, Harlow, UK.

Received: 20 February 2017 Accepted: 13 May 2017 Published electronically: 30 September 2017 